\title{
Hiding among traps? Mortality of early instar odonate larvae in the presence of bladderwort plants
}

\author{
Sandra Manasov and Frank Suhling (D)* \\ Landscape Ecology and Environmental Systems Analysis, Institute of Geoecology, Technische Universität \\ Braunschweig, Braunschweig, Germany
}

(Received 6 November 2019; accepted 16 January 2020)

\begin{abstract}
We investigated the effects of the presence of bladderwort plants on survival of early instar larvae of one coenagrionid and two libellulids in laboratory experiments. In all three species survival was reduced compared to treatments with a non-carnivorous submerged plant, with effective mortality that could be related to bladderwort being 19-45\% dependent on the prey species. Individuals of all species were found in capture bladders. We also recorded the microhabitat use of the early instar larvae and found that the species with highest use of vegetation had highest mortality due to bladderwort. We conclude that bladderwort may have effects on odonate larvae that translate into natural conditions and we discuss factors that may affect predation by bladderwort on odonates in the field.
\end{abstract}

Keywords: Crocothemis erythraea; Ischnura elegans; Libellula quadrimaculata; microhabitat use; predation; Utricularia vulgaris; dragonfly; Odonata

\section{Introduction}

Odonate larvae possess many natural enemies, such as fish, water birds, amphibia and various invertebrate predators including other odonate larvae (Corbet, 1999). The presence or absence of fish in particular often shapes odonate communities, as confirmed for Enallagma and Lestes communities in North America (McPeek, 1990; Stoks \& McPeek, 2003). Dragonfly larvae have developed diverse behavioural and morphological features serving to reduce predation pressure, which involve traits for defence, escape, and crypsis (Suhling et al., 2015, table 35.2). The latter comprises behavioural traits such as reduced locomotory activity, which may be fixed as well as flexible, and depending on the type or species of predator (Johnson, 1991; Wohlfahrt, Mikolajewski, Joop, \& Suhling, 2006). Particularly in species that have larvae belonging to the sprawler type, such as most Coenagrionidae and many Aeshnidae and Libellulidae (Corbet, 1962; Suhling et al., 2015), hiding among aquatic vegetation serves to reduce predation against fish as well as against invertebrates (Elkin \& Baker, 2000; Henrikson, 1993; Thompson, 1987; Wellborn \& Robinson, 1987). Predation pressure decreases with increasing weed density (Thompson, 1987) and is also influenced by the plant growth forms (Dionne, Butler, \& Folt, 1990; Dionne \& Folt, 1991). However, if it is generally assumed that aquatic plants may reduce the predation risk of

*Corresponding author. Email: f.suhling@tu-bs.de 
odonate larvae (Corbet, 1999, p. 164), there may be exceptions if the plant itself is the predator (Martens \& Grabow, 2011).

Bladderworts (genus Utricularia, Lentibulariaceae) are globally distributed carnivorous plants in freshwater systems. The plants capture small invertebrates by means of bladder-like traps (Reifenrath, Theisen, Schnitzler, Porembski, \& Barthlott, 2006; Sanabria-Aranda et al., 2006), which provide additional nutrients (Friday, 1989). Whereas the relevance of the carnivory for the plant is debated (Kibriya \& Iwan Jones, 2007; Knight, 1992; Richards, 2001), there is no doubt that many different organisms get trapped in the bladders. Enclosure experiments revealed that predation by bladderwort caused a decrease in prey density over time (Baumgartner, 1987; Harms, 2002). The known prey includes various microalgae, Protozoa, Oligochaeta, Rotifera, Crustacea (Cladocera, Copepoda, Ostracoda), and insect larvae, including Diptera (Chironomidae, Culicidae), Heteroptera (Corixidae), and Ephemeroptera (Caenidae) (Alkhalaf, Hübener, \& Porembski, 2009; Baumgartner, 1987; Harms, 1999; Sanabria-Aranda et al., 2006; Walker, 2004). The prey organisms all have a size comparable to early instar odonate larvae. But, only recently, early instar larvae of Coenagrionidae and Aeshnidae have been discovered in capture bladders of Utricularia australis R. Brown in a garden pond (Herzog \& Martens, 2013; Martens \& Grabow, 2011).

We became interested in these observations because bladderwort can be a dominant aquatic vegetation at sites with huge dragonfly populations and one should expect clearly detectable interactions. On the other hand, even in studies where the prey captured by bladderwort was carefully compared against the assemblages of organisms, living in its plant stand, Odonata larvae remained undetected in traps of Utricularia (Baumgartner, 1987; Sanabria-Aranda et al., 2006). Thus, is predation by bladderwort on early instar larvae just a matter of random misfortune or could it have quantitative effects on the populations? Our aim was to quantify predation by bladderwort. We analysed mortality caused by the common bladderwort Utricularia vulgaris Linnaeus by comparing decreases in numbers of early instar larvae in containers with bladderwort and a non-carnivorous plant in the laboratory. We did that for three species of Odonata, one Coenagrionidae and two Libellulidae. Finally, we also recorded microhabitat use by the larvae of the three species in treatments with and without bladderwort.

\section{Methods}

\section{Study species and study area}

Our study organisms included early instar larvae of three odonate species and two water plants. The odonates were Ischnura elegans (Vander Linden, 1820), Crocothemis erythraea (Brullé, 1832), and Libellula quadrimaculata Linnaeus, 1758. First experiments were done with $L$. quadrimaculata larvae in 2018 for reason of availability of egg clutches. But, since in nature the larvae of L. quadrimaculata mainly dwell on bottom substrates and less so in vegetation (Wildermuth \& Martens, 2019), we aimed to compare with species that use submerged vegetation as main microhabitat in 2019. Both I. elegans and C. erythraea are such species, although larvae can be found on bottom substrates of ponds, C. erythraea more commonly so than $I$. elegans (Wildermuth \& Martens, 2019).

For obtaining young instar larvae, we caught females in the field. In I. elegans the female was kept for 12 hours over night in a small closed container with air contact, water, small sticks and a filter paper as a macrophyte replacement, which was accepted for oviposition. The eggs of the two libellulids were collected by dipping the abdomen into a jar with water, which was followed by immediate egg laying (cf. Schenk, Suhling, \& Martens, 2004). We used one egg clutch of $I$. elegans, one of C. erythraea and two of L. quadrimaculata. The eggs were kept in the laboratory at $20^{\circ} \mathrm{C}$ until hatching of the larvae. For all experiments second instar larvae were used. 
The water plants used in our experiments were $U$. vulgaris and Myriophyllum spicatum L. Both plants were collected from an aggregation of several ponds situated in the northeastern suburban area of the city district of Braunschweig $\left(52.33032^{\circ} \mathrm{N}, 10.58186^{\circ} \mathrm{E}\right)$, which are rich in aquatic vegetation and odonate species (Suhling, Martens, Leipelt, Schütte, \& Hoppe-Dominik, 2009). In the case of $U$. vulgaris these ponds are the major habitat in the area and $U$. vulgaris is among the dominant plants there. Myriophyllum spicatum occurs in many ponds in the area. Stems of both plants were taken from the ponds and transferred to the laboratory where they were kept at ambient temperature of $20^{\circ} \mathrm{C}$ and a day/night rhythm of $14 / 10$ hours. The light intensity was 1600 lux.

The bladderwort $U$. vulgaris is free-floating and does not put down roots. The stems can attain lengths of $>1 \mathrm{~m}$ in a single growing season. From the main axis branch off smaller stems with photosynthetic leaves with about 20 traps or bladders (Friday, 1992). The bladders are 0.3-5.0 $\mathrm{mm}$ in diameter and closed with a trap door. Antennae trigger the trap mechanism after being touched (Friday, 1989; Meyers \& Strickler, 1979). Within 10-15 ms, the trap door opens and the prey are drawn in by a negative pressure of -15 to $-17 \mathrm{kPa}$. That mechanism resets within 30 minutes (Adamec, 2011). The main stem grows at one end while it slowly dies at the other but 1200-2700 bladders are functional simultaneously (Friday, 1989). Myriophyllum spicatum is a submerged, aquatic perennial that can have stems 1.8-6 m in length with soft and feather-like leaves, and each mature submerged leaf has a central midrib with 12-20 filiform segments on each side. Although the two plants are not fully similar in appearance we assumed that they may be similar enough that both may serve as shelter for odonate larvae.

\section{Experimental design and analyses}

We compared survival of young instar larvae in the presence of stalks of $U$. vulgaris with treatments where stalks of $M$. spicatum were provided as perches. The experiments were conducted in containers $6 \mathrm{~cm}$ wide, $7.5 \mathrm{~cm}$ long, and $2.5 \mathrm{~cm}$ high, which were half filled with dechlorinated tap water. The temperature and light conditions were as above. The vegetation density was kept equal in the experimental containers: the water volume was about $80 \%$ filled with plant material. For convenience, the treatments will be termed Utricularia- and Myriophyllum-treatment in the following. In each replicate 20 larvae were introduced immediately after hatching from the egg (Figure 1). The replicates were started successively when enough larvae (i.e. 40) had hatched to prepare at least one replicate for each treatment. Each run of the experiment was stopped after 10 days. Artemia salina naupliae were added to the containers once per day serving as prey for the odonate larvae. For each replicate we used new odonate larvae as well as new plant material.

For detecting larvae, the plant stalks were transferred carefully to a Petri dish filled with water and searched for larvae. The numbers of larvae found by this method were considered as survivors. To avoid disturbance, we did not check bladders of $U$. vulgaris for larvae during the experiment. However, we examined samples of bladders after the experiment using a dissecting microscope. Because of these limitations, we cannot provide absolute numbers of larvae captured in bladders. A somewhat makeshift method was used for identifying microhabitat use by the larvae. For this it was noted how many larvae were climbing to the plants and how many were found on the bottoms of the containers when checking for larvae. Since the numbers of survivors usually did not resemble the initial numbers of larvae in the container we used the proportions of larvae on plants in relation to the surviving larvae per container for later analysis.

For statistical analyses, we ran two-way ANOVAs with species and treatment as independent factors. Numbers of survivors per container and proportions of larvae on plants served as response variables in two separate analyses. The data were $\log (x+1)$ transformed for the purpose of the tests. In figures the original data are shown. We used Tukey's posthoc tests for 


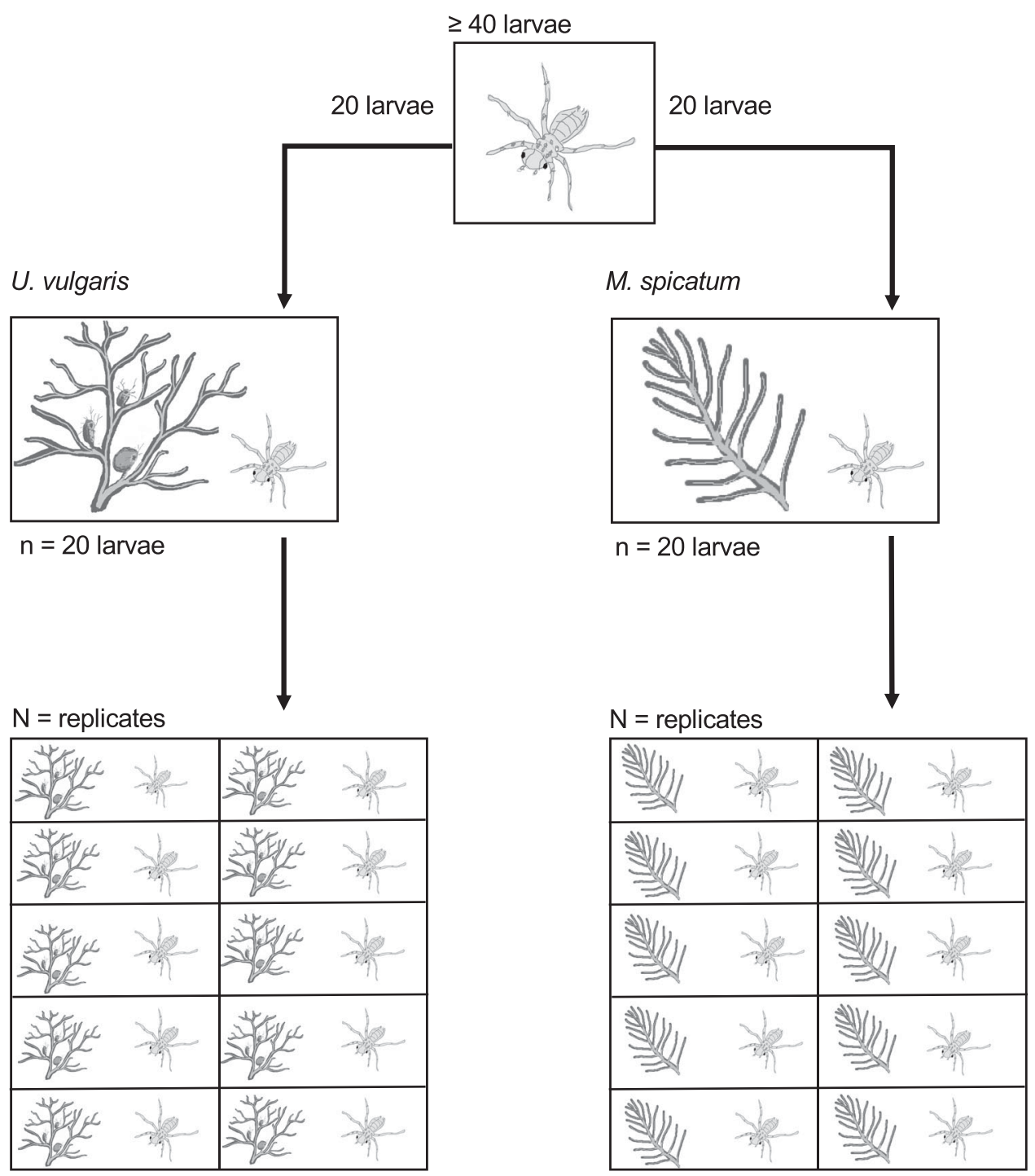

Figure 1. Flow chart depicting the methods. Odonate larva and plant are not to scale; compare to photos in Figure 3.

pairwise comparisons between the treatments in each odonate species. The analyses were run in the software Past 3.24 (Hammer, Harper, \& Ryan, 2001). The numbers of replicates are presented in Table 1.

\section{Results}

\section{Mortality}

The numbers of surviving larvae varied significantly with the treatment (ANOVA, $\mathrm{F}_{1,86}=70.46$, $p<0.001)$ and between the odonate species $\left(\mathrm{F}_{2,86}=19.90, p<0.001\right)$ (Figure 2). Pairwise posthoc tests revealed that the numbers of surviving larvae differed between the treatments in all three odonate species, with survival always lowest in presence of Utricularia. There was 
Table 1. Numbers of replicates in the different treatments and analyses. In each replicate 20 larvae were exposed to the plants. Note that the replicates for the microhabitat analysis is lower because in the first runs with L. quadrimaculata the larval position was not noted.

\begin{tabular}{lcccc}
\hline & \multicolumn{4}{c}{ Replicates per treatment } \\
\cline { 2 - 4 } & \multicolumn{2}{c}{ Utricularia-treatment } & \multicolumn{2}{c}{ Myriophyllum-treatment } \\
\cline { 2 - 4 } Odonate species & Survival & Microhabitat & Survival & Microhabitat \\
\hline Ischnura elegans & 10 & 10 & 10 & 10 \\
Crocothemis erythraea & 13 & 13 & 11 & 11 \\
Libellula quadrimaculata & 23 & 17 & 25 & 15 \\
\hline
\end{tabular}

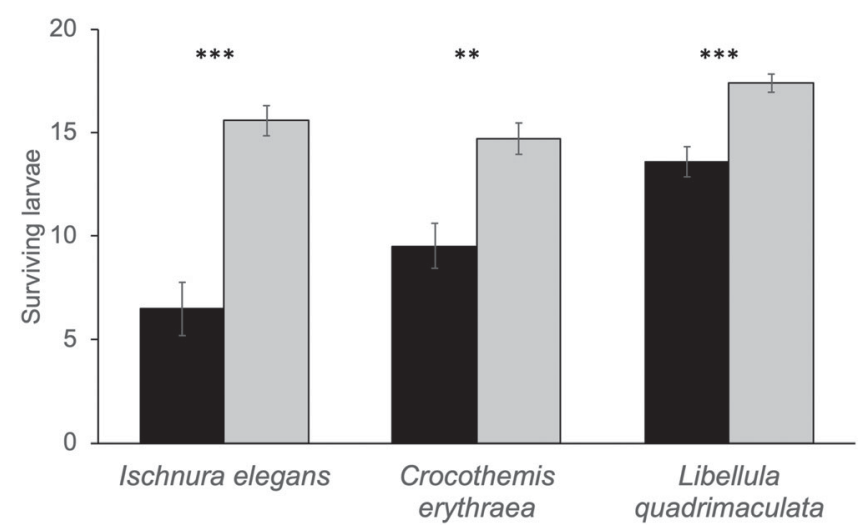

Figure 2. Mean numbers of surviving larvae $( \pm \mathrm{SE})$ in treatments with Utricularia vulgaris (black bars) and Myriophyllum spicatum (shaded bars). Pairwise posthoc tests: $* * p<0.01$, ***p $p 0.001$.

also a significant interaction between treatment and species $\left(\mathrm{F}_{2,86}=5.24, p=0.007\right)$, i.e. the effect of treatment differed in strength between species. The decline of survival in the Utricularia treatment was much more severe in the case of I. elegans compared to the two other species. The proportions of mortality in the Utricularia-treatments relative to the Myriophyllumtreatments, where mortality was quite similar in all species, were $45.5 \%$ for I. elegans, $25.9 \%$ for C. erythraea, and $18.9 \%$ for L. quadrimaculata.

On closer examination, we found small larvae of all three odonate species in the bladders of U. vulgaris, one of I. elegans, two of C. erythraea and 11 of L. quadrimaculata (cf. Figure 3a). This did not comprise all larvae missing from the replicates, which was not surprising due to the 10-day running time of the experiment and the fact that we did not check for larvae in all the bladders.

\section{Larval microhabitat use}

Larvae were in most cases found more commonly on the bottom of the containers than on the plants, which may be to some extent an artefact of handling. However, even after handling many larvae were crawling on the plant stems, often in close vicinity of the bladders of $U$. vulgaris (Figure 3b, c). The mean proportion of larvae of I. elegans and C. erythraea found on the plants was higher than 0.5 in the Utricularia-treatments. In the Myriophyllum-treatments larvae were proportionally underrepresented on the plants in all cases (Figure 4). Two-way ANOVA revealed significant differences between the treatments $\left(\mathrm{F}_{1,76}=29.76, p<0.001\right)$ and also between the odonate species $\left(\mathrm{F}_{2,76}=6.41, p=0.003\right)$, while the interaction was not significant 

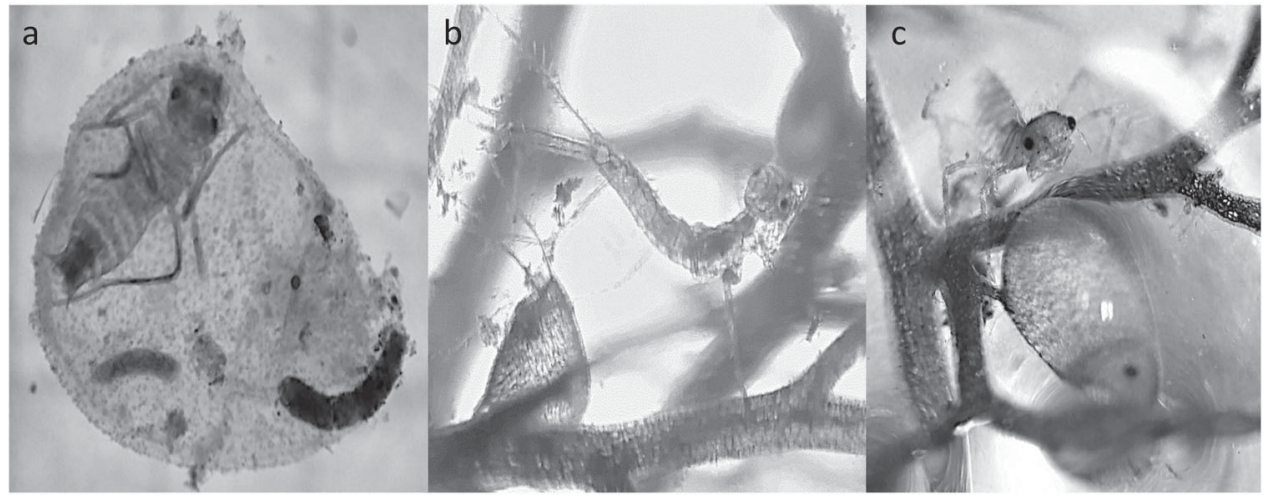

Figure 3. (a) Second instar larva of Libellula quadrimaculata found dead in a bladder of Utricularia vulgaris. (b) Living second instar larva of Ischnura elegans next to a bladder of $U$. vulgaris. (c). Living second instar larva of Crocothemis erythraea next to a bladder of $U$. vulgaris.

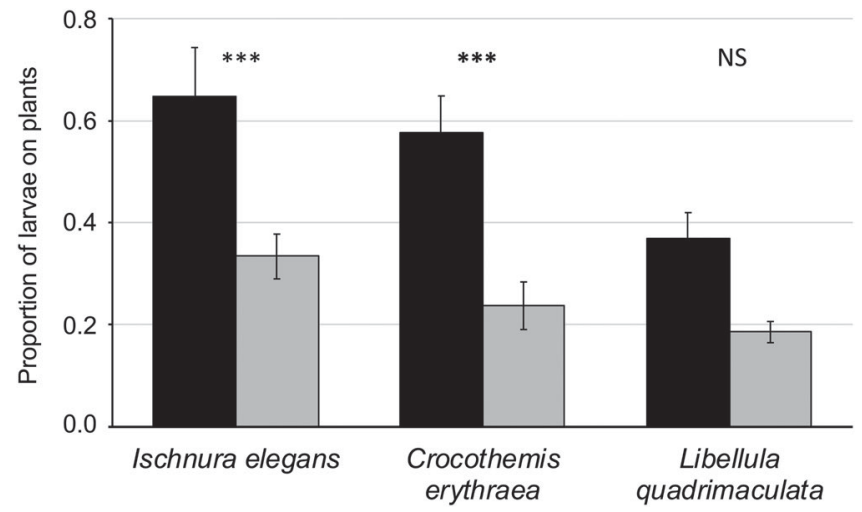

Figure 4. Mean proportions ( $\pm \mathrm{SE}$ ) of larvae perching on plants in treatments with Utricularia vulgaris (black bars) and Myriophyllum spicatum (shaded bars). Pairwise posthoc tests: *** $p<0.001$, NS not significant.

$\left(\mathrm{F}_{2,76}=1.61, p=0.207\right)$. Pairwise comparisons showed that significant differences between treatments occurred in I. elegans and C. erythraea but not in L. quadrimaculata (Figure 4).

\section{Discussion}

Early instar larvae of both Coenagrionidae and Aeshnidae have been recorded in bladders of U. australis (Herzog \& Martens, 2013; Martens \& Grabow, 2011). In our study, we add $U$. vulgaris to the (short) list of plants preying on early instar odonate larvae. We suppose that other bladderwort species are also capable of preying on early instar Odonata. We also confirm that larvae of Coenagrionidae can be victims of bladderwort and add two species of Libellulidae to the list of prey. We suppose that early instars of most odonate species may be affected - as long as they come somehow in contact with aquatic bladderwort plants.

So far, there was no quantification of the mortality risk for early instar odonate larvae due to bladderwort predation. We found that, at least under the experimental conditions, the number of larvae killed by $U$. vulgaris may be severe. This is under the assumption that the differences in survival between the Utricularia- and the Myriophyllum-treatments were caused by bladderwort. This is supported by the fact that we found larvae in the bladders at the end of the experiments and by the record of larvae in bladders in the field (Martens \& Grabow, 2011). 
There were significant differences in mortality between the three odonate species tested. Yet, the predatory effect by bladderwort is likely not species-specific. However, we suppose that the larval lifestyle and behaviour shapes the predation risk. In our experiments I. elegans was the species with the most distinct use of bladderwort versus the bottom, followed by $C$. erythraea, and L. quadrimaculata. This result fits relatively well expectations, considering the known pattern of habitat use of the three species, with I. elegans probably most clearly related to aquatic vegetation (cf. Study Species), whereas L. quadrimaculata larvae dwell in vegetation as well as in bottom substrates. It is likely that the more the larvae of a species sprawl in vegetation the higher their risk of becoming prey to bladderwort. However, prey behaviour may also play a role (Harms \& Johansson, 2000). For instance, early instar larvae of C. erythraea are active, visual hunters; they move towards sensed prey when foraging (Suhling, Sahlén, Kasperski, \& Gaedecke, 2005). During such actions they probably more regularly touch the antennae of Utricularia and, consequently, have higher risk of being captured than less active hunters. The same may be true for I. elegans (cf. Heads, 1985).

We found much less use of M. spicatum than of $U$. vulgaris by the odonate larvae. This has no relevant effect on the interpretation of the predatory effects of bladderwort, since the non-carnivorous plant was less used than the carnivorous one. Nevertheless, it demands some explanation. We only can imagine that the plant structure, which is a bit simpler in M. spicatum, may have caused larvae to slide off the leaves more often when being transferred to Petri jars for counting. We actually cannot exclude that that happened with both plants, but maybe less so with bladderwort. The consequence would be that the use of plants in both cases may be underestimated.

A mortality of $19 \%$ due to bladderwort was found in L. quadrimaculata and $45 \%$ in I. elegans; however, the most relevant question is whether mortality under experimental conditions somehow translates into natural conditions. Several factors may affect the predation by bladderwort on odonate larvae. The efficiency of bladderwort to catch prey depends on age, size and position of bladders (Friday, 1989) as well as on the condition of the plant. The optimal conditions for building traps are complex and not fully understood, particularly the influence of nutrient availability, which depends on the environment (Englund \& Harms, 2003; Knight, 1992). Under bad conditions, such as low carbon dioxide concentrations in the water and low light intensity, the investment in trap building declined or stopped (Friday, 1989; Harms, 2002). Then, predation by bladderwort would be massively reduced. Also, phenology of plant and odonate larvae have to be synchronised. At least in our experimental system this seems to be the case. Usually, fully functional traps are built in the middle of April and trap building continues during summer (Friday, 1989). That resembles the reproductive season of Odonata in the region, so traps would be present at all times together with early instar larvae of at least some species.

In nature, high density of other prey such as microcrustaceans may prevent odonate larvae from being captured. In our experiments Artemia was present at least once per day. But, since the survival time of Artemia is not very long in fresh water there was probably not enough other prey for the bladderwort than the odonates. On the other hand, it seems that plankton prey is less common in bladders compared to organisms living among vegetation (Harms, 1999). Also, interactions between prey species may cause that certain prey species to be overrepresented as prey (Harms \& Johansson, 2000).

Finally, the predatory effect of bladderwort versus its efficiency as shelter against other predators is relevant. A mesocosm experiment, although with a different study aim, provided interesting results (Knorp \& Dorn, 2016). Interactions of mosquitofish (Gambusia holbrooki Girard, 1859) and presence of vegetation were investigated with bladderwort being used as submerged vegetation. Dragonflies were able to colonise the mesocosms via oviposition and dragonfly emergence from mesocosms was measured. In the presence of fish, emergence was higher when bladderwort plants were present (Knorp \& Dorn, 2016). Thus, compared to 
conditions without any submerged vegetation the bladderwort is surely still reducing predation by fish. However, with other vegetation the anticipated antipredation effect may be higher. So far there is no study on predation by fish or invertebrates in treatments comparing between bladderwort and non-carnivorous plants.

In conclusion, it seems possible that bladderwort can be a notable predator for early instar larvae, which use submerged aquatic vegetation as microhabitat, even if they have not often been recorded yet as prey. The predatory effects may be particularly relevant in species that hide between plants as an antipredation behaviour. Most likely, there will be only predation on very small larvae that fit the size of the bladders. It still has to be investigated to which size larvae are caught. For small larvae the bladderwort plant may provide a shelter against other predators but as well a trap. One may expect a behavioural conflict, comparable to conflicts such as antipredation versus anti-parasite behaviour or anti-predation versus avoiding aggressive encounters with conspecifics (Baker \& Smith, 1997; Elkin \& Baker, 2000). Interesting in this context is that the larvae were running along stems of bladderwort without avoiding the bladders. Maybe they do not recognise the bladders as a threat. For a better evaluation of the population effects more studies are necessary, e.g. considering the plant density, the time of the year, and the mortality due to bladderwort in relation to the protection the plant may provide against other predators.

\section{Acknowledgements}

We thank Andreas Martens for inspiration and mental support. Diana Goertzen, Fabian Manasov, Felix Bobbermin, and Hanna Dedenbach assisted in the field. Jolan Hogreve helped feed the larvae.

\section{ORCID}

Frank Suhling (D) http://orcid.org/0000-0003-2922-0261

\section{References}

Adamec, L. (2011). Functional characteristics of traps of aquatic carnivorous Utricularia species. Aquatic Botany, 95(3), 226-233. doi:10.1016/j.aquabot.2011.07.001

Alkhalaf, I. A., Hübener, T., \& Porembski, S. (2009). Prey spectra of aquatic Utricularia species (Lentibulariaceae) in northeastern Germany: The role of planktonic algae. Flora - Morphology, Distribution, Functional Ecology of Plants, 204, 700-708. doi:10.1016/j.flora.2008.09.008

Baker, R. L., \& Smith, B. P. (1997). Conflict between antipredator and antiparasite behaviour in larval damselflies. Oecologia, 109, 622-628. doi:10.1007/s004420050125

Baumgartner, D. L. (1987). Laboratory evaluation of the bladderwort plant Utricularia vulgaris (Lentibulariaceae), as a predator of late instar Culex pipiens and assessment of its biocontrol potential. Journal of the American Mosquito Control Association, 3, 504-507.

Corbet, P. S. (1962). A Biology of Dragonflies (Reprint 1983, Classey, Oxon ed. Vol. Reprint 1983). London: Witherby.

Corbet, P. S. (1999). Dragonflies: behaviour and ecology of Odonata. Colchester: Harley Books.

Dionne, M., Butler, M., \& Folt, C. (1990). Plant-specific expression of antipredator behaviour by larval damselflies. Oecologia, 83, 371-377. doi:10.1007/BF00317562

Dionne, M., \& Folt, C. L. (1991). An experimental analysis of macrophyte growth forms as fish foraging habitat. Canadian Journal of Fisheries and Aquatic Sciences, 48, 123-131. doi:10.1139/cjfas-2014-0210

Elkin, C. M., \& Baker, R. L. (2000). Lack of preference for low-predation-risk habitats in larval damselflies explained by costs of intraspecific interactions. Animal Behaviour, 60, 511-521. doi:10.1006/anbe.2000.1513

Englund, G., \& Harms, S. (2003). Effects of light and microcrustacean prey on growth and investment in carnivory in Utricularia vulgaris. Freshwater Biology, 48, 786-794. doi:10.1046/j.1365-2427.2003.01042.x

Friday, L. E. (1989). Rapid turnover of traps in Utricularia vulgaris L. Oecologia, 80, 272-277. doi:10.1007/BF00380163

Friday, L. E. (1992). Measuring investment in carnivory: seasonal and individual variation in trap number and biomass in Utricularia vulgaris L. New Phytologist, 121, 439-445. doi:10.1111/j.1469-8137.1992.tb02944.x

Hammer, Ø., Harper, D. A. T., \& Ryan, P. D. (2001). Past: paleontological statistics software package for education and data analysis. Paleontologica Electronica, 4, 1-9.

Harms, S. (1999). Prey selection in three species of the carnivorous aquatic plant Utricularia (bladderwort). Fundamental and Applied Limnology, 146, 449-470. doi:10.1127/archiv-hydrobiol/146/1999/449 
Harms, S. (2002). The effect of bladderwort (Utricularia) predation on microcrustacean prey. Freshwater Biology, 47, 1608-1617. doi:10.1046/j.1365-2427.2002.00897.x

Harms, S., \& Johansson, F. (2000). The influence of prey behaviour on prey selection of the carnivorous plant Utricularia vulgaris. Hydrobiologia, 427, 113-119. doi:10.1023/A:1003961614595

Heads, P. A. (1985). The effect of invertebrate and vertebrate predators on the foraging movement of Ischnura elegans larvae (Odonata: Zygoptera). Freshwater Biology, 15, 559-571. doi:10.1111/j.1365-2427.1985.tb00226.x

Henrikson, B.-I. (1993). Sphagnum mosses as a microhabitat in acidified lakes and the colour adaption and substrate preference in Leucorrhina dubia (Odonata, Anisoptera). Ecography, 16, 143-153. doi:10.1111/j.1600-0587. 1993.tb00066.x

Herzog, J., \& Martens, A. (2013). Larve von Aeshna spec. (Odonata: Aeshnidae) als Beute des Südlichen Wasserschlauchs Utricularia australis. Libellula, 32, 181-185.

Johnson, D. M. (1991). Behavioural ecology of larval dragonflies and damselflies. Trends in Ecology and Evolution, 6 , 8-13. doi:10.1016/0169-5347(91)90140-S

Kibriya, S., \& Iwan Jones, J. (2007). Nutrient availability and the carnivorous habit in Utricularia vulgaris. Freshwater Biology, 52, 500-509. doi:10.1111/j.1365-2427.2006.01719.x

Knight, S. E. (1992). Costs of carnivory in the common bladderwort, Utricularia macrorhiza. Oecologia, 89, 348-355. doi:10.1007/BF00317412

Knorp, N. E., \& Dorn, N. J. (2016). Mosquitofish predation and aquatic vegetation determine emergence patterns of dragonfly assemblages. Freshwater Science, 35, 114-125. doi:10.1086/684678

Martens, A., \& Grabow, K. (2011). Early stadium damselfly larvae (Odonata: Coenagrionidae) as prey of an aquatic plant, Utricularia australis. International Journal of Odonatology, 14, 101-104. doi:10.1080/13887890.2011.568191

McPeek, M. A. (1990). Determination of species composition in the Enallagma damselfly assemblages of permanent lakes. Ecology, 71, 83-98. doi:10.2307/1940249

Meyers, D. G., \& Strickler, J. R. (1979). Capture enhancement in a carnivorous aquatic plant: function of antennae and bristles in Utricularia vulgaris. Science, 203, 1022-1025. doi:10.1126/science.203.4384.1022

Reifenrath, K., Theisen, I., Schnitzler, J., Porembski, S., \& Barthlott, W. (2006). Trap architecture in carnivorous Utricularia (Lentibulariaceae). Flora - Morphology, Distribution, Functional Ecology of Plants, 201, $597-605$. doi:10.1016/j.flora.2005.12.004

Richards, J. H. (2001). Bladder function in Utricularia purpurea (Lentibulariaceae): is carnivory important? American Journal of Botany, 88, 170-176.

Sanabria-Aranda, L., González-Bermúdez, A., Torres, N. N. E. D., Guisande, C., Manjarrés-Hernández, A. N. A., Valoyes-Valois, V., \& Duque, S. R. (2006). Predation by the tropical plant Utricularia foliosa. Freshwater Biology, 51, 1999-2008. doi:10.1111/j.1365-2427.2006.01638.x

Schenk, K., Suhling, F., \& Martens, A. (2004). Relation between egg distribution, mate guarding intensity, and offspring characteristics in dragonflies (Odonata). Animal Behaviour, 68, 599-606. doi:10.1016/j.anbehav.2003.12.010

Stoks, R., \& McPeek, M. A. (2003). Predators and life histories shape Lestes damselfly assemblages along a freshwater habitat gradient. Ecology, 84, 1576-1587. doi:10.1890/0012-9658(2003)084[1576:PALHSL]2.0.CO;2

Suhling, F., Martens, A., Leipelt, K. G., Schütte, C., \& Hoppe-Dominik, B. (2009). Libellen Braunschweigs - Verbreitungsmuster und Bestandstrends der Libellenfauna einer Großstadt (Odonata). Braunschweiger Naturkundliche Schriften, 8, 449-476.

Suhling, F., Sahlén, G., Gorb, S., Kalkman, V. J., Dijkstra, K.-D. B., \& van Tol, J. (2015). Order Odonata. In Thorp, J. H. \& Rogers, C. (Eds.), Thorp and Covich's Freshwater Invertebrates (pp. 893-932). London: Academic Press.

Suhling, F., Sahlén, G., Kasperski, J., \& Gaedecke, D. (2005). Behavioural and life history traits in temporary and perennial waters: comparisons among three pairs of sibling dragonfly species. Oikos, 108, 609-617. doi:10.1111/j.0030-1299.2005.13230.x

Thompson, D. J. (1987). Regulation of damselfly populations: the effects of weed density on larval mortality due to predation. Freshwater Biology, 17, 367-371. doi:10.1111/j.1365-2427.1987.tb01056.x

Walker, I. (2004). Trophic interactions within the Utricularia habitat in the reservoir of the Balbina hydroelectric powerplant (Amazonas, Brazil). Acta Limnologica Brasiliensia, 16, 183-191.

Wellborn, G. A., \& Robinson, J. V. (1987). Microhabitat selection as an antipredator strategy in the aquatic insect Pachydiplax longipennis Burmeister (Odonata: Libellulidae). Oecologia, 71, 185-189. doi:10.1007/BF00377283

Wildermuth, H., \& Martens, A. (2019). Die Libellen Europas: alle Arten von den Azoren bis zum Ural. Wiebelsheim: Quelle \& Meyer.

Wohlfahrt, B., Mikolajewski, D. J., Joop, G., \& Suhling, F. (2006). Are behavioural traits in prey sensitive to the risk imposed by predatory fish? Freshwater Biology, 51, 76-84. doi:10.1111/j.1365-2427.2005.01475.x 